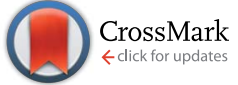

Cite this: RSC Adv., 2017, 7, 6622
Received 7th November 2016 Accepted 27th December 2016

DOI: 10.1039/c6ra26454a

www.rsc.org/advances

\section{Prevention of active-site destruction during the synthesis of high performance non-Pt cathode catalyst for fuel cells $\uparrow$}

\begin{abstract}
Rui Li, ${ }^{a}$ Yu Jun Ge, ${ }^{b}$ Fan He, ${ }^{b}$ Li Ting Dou, ${ }^{b}$ Bin Hong Liu ${ }^{c}$ and Zhou Peng Li ${ }^{\star b}$
Active-site destruction during the synthesis of porous non-Pt catalysts for the oxygen reduction reaction (ORR) is investigated in detail. Because of the carbon erosion caused by $\mathrm{CO}_{2}$ generated from the decomposition of $\mathrm{CaCO}_{3}$ template, active-sites are destroyed during the formation of the macroporous carbon-supported cobalt catalyst (Co/N-MPC) using Co-coordinated glucose-urea resin and a $\mathrm{CaCO}_{3}$ template. Removal of the $\mathrm{CaCO}_{3}$ template before its decomposition can effectively suppress this site destruction, thereby leading to a higher content of catalytic nitrogen species in the catalyst. Nitrogencontaining active-sites are unstable at temperatures over $800^{\circ} \mathrm{C}$. After optimizing the template removal and carbonization temperatures, the synthesized Co/N-MPC exhibits high catalytic activity towards ORR in both alkaline and acidic electrolytes. Its electron transfer number reaches 3.65 in alkaline and 3.75 in acidic electrolytes, respectively. The direct borohydride fuel cell with the synthesized Co/N-MPC shows a power density as high as $215 \mathrm{~mW} \mathrm{~cm}^{-2}$, which is comparable to that of the cell using $28.6 \mathrm{wt} \% \mathrm{Pt} / \mathrm{C}$ as a cathode catalyst under ambient conditions.
\end{abstract}

\section{Introduction}

A fuel cell is a device that converts chemical energy from certain fuels into electricity through an electro-oxidation reaction of fuel at the anode and an electro-reduction reaction of oxygen at the cathode. The performance of a fuel cell greatly relies on the kinetics of oxygen reduction reaction (ORR). The catalytic activity of the cathode catalyst is one of the most crucial factors in enhancing ORR. Platinum is a highly active catalyst for ORR, but its high-cost hinders fuel cell commercialization. Therefore, cheap non-Pt catalysts are attracting significant attention. They demonstrate high performance comparable to commercial $\mathrm{Pt} / \mathrm{C}$ catalysts, with lower cost. ${ }^{1,2}$ In particular, some porous carbonsupported catalysts have shown a great potential for fuel cell applications. ${ }^{3,4}$

Most carbon-supported non-Pt catalysts catalyze ORR on active-sites such as $\mathrm{M}-\mathrm{N}_{x}$ ( $\mathrm{M}$ stands for transition metal), pyridinic-N, and graphitic-N. ${ }^{5-10}$ The number of these sites on the carbon support determines their catalytic activities. ${ }^{11}$ Macroporous carbon (MPC) with high electrical conductivity is a promising carbon support because its large specific surface area ensures the capability to support more active-sites. ${ }^{\mathbf{1 2 , 1 3}}$

${ }^{a}$ Chu Kochen Honors College, Zhejiang University, Hangzhou, China ${ }^{b}$ College of Chemical \& Biological Engineering, Zhejiang University, Hangzhou, China. E-mail: zhoupengli@zju.edu.cn; Fax: +86-571-87953149; Tel: +86-571-87953149 ${ }^{c}$ College of Materials Science \& Engineering, Zhejiang University, Hangzhou, China † Electronic supplementary information (ESI) available. See DOI: 10.1039/c6ra26454a
Unlike conventional carbon-supported catalysts, such as Pt/XC72 in which an active-site (Pt) exists on the surfaces of solid carbon particles (XC-72), MPC-supported catalysts present active-sites on the inner pore surfaces. ${ }^{\mathbf{1 4}}$

MPC-supported catalysts are fabricated using the templateassisted method, via the carbonization of a composite consisting of a catalyst precursor and a template. The carbonization temperature and nature of the applied template significantly influence the active-site formation. Zeolite, silica, titania, and calcium carbonate are widely-used templates. ${ }^{15-33}$ However, zeolite, silica, and titania templates have to be removed by strong acids, leading to serious environmental problems in large-scale production. ${ }^{34}$ In contrast, a cheap $\mathrm{CaCO}_{3}$ template can be removed under mild conditions. $\mathrm{CaCO}_{3}$ decomposes into $\mathrm{CaO}$ and $\mathrm{CO}_{2}$ during carbonization. $\mathrm{CO}_{2}$ reacts with carbon to form $\mathrm{CO}$, probably causing catalyst deterioration by activesite destruction. However, little attention has been paid to the effect of the employed template on the active-site destruction.

It has been reported that the formed Fe nanoparticles may destroy the active-sites during non-Pt catalyst preparation at a carbonization temperature over $700{ }^{\circ} \mathrm{C} .{ }^{35}$ Removal of Fe species before active-site destruction effectively suppresses the nitrogen loss. ${ }^{36}$ This study investigates the influences of carbonization temperature and $\mathrm{CO}_{2}$ during catalyst synthesis on the catalytic activity towards ORR. Based on physical characterizations and electrochemical analyses, we attempt to figure out the relationship between active-site destruction and performance decline. Moreover, a strategy to suppress the active-site destruction is suggested. Verified in a direct 
borohydride fuel cell (DBFC), a high-performance ORR catalyst (Co/N-MPC) is presented after optimizing the catalyst synthesis conditions for the suppression of active-site destruction. The DBFC is an alkaline fuel cell with high electromotive force (1.64 V) and theoretical energy conversion efficiency (91\%), using alkaline borohydride solution as the anode fuel. ${ }^{37,38}$ The DBFC with Nafion membrane is a simple and convenient model cell for the evaluation of an ORR catalyst. ${ }^{39}$

\section{Method and procedures}

\subsection{Catalyst preparation}

Ethyl silicate $\left(\mathrm{Si}_{(}\left(\mathrm{OC}_{2} \mathrm{H}_{5}\right)_{4}: 12 \mathrm{~mL}\right)$ was added dropwise to an ammonium hydroxide solution $(2 \mathrm{M}, 200 \mathrm{~mL})$ under stirring for $4 \mathrm{~h}$. Nanosphere silica was then obtained after centrifugal separation and drying in vacuum for $6 \mathrm{~h}$.

Glucose monohydrate (11.00 g) and urea (1.67 g) were dissolved in 6 and $2 \mathrm{~mL}$ of deionized water, respectively. The urea solution was then added to the glucose solution and stirred for $40 \mathrm{~min}$ at $90{ }^{\circ} \mathrm{C}$ for the polymerization of glucose-urea resin. Cobalt nitrate solution $(10 \mathrm{~mL})$ containing $2.91 \mathrm{~g}$ of $\mathrm{Co}\left(\mathrm{NO}_{3}\right)_{2}$ was then added and stirred for $30 \mathrm{~min}$ to prepare the Cocoordinated glucose-urea resin. The obtained resin solution was then mixed with an emulsion containing $20.00 \mathrm{~g}$ of the template (nano $\mathrm{SiO}_{2}$ or $\mathrm{CaCO}_{3}$ ) in a $20 \mathrm{~mL}$ of deionized water to form a homogeneous suspension. After $1 \mathrm{~h}$ of evaporation at $80^{\circ} \mathrm{C}$, the obtained composite was pretreated at $110^{\circ} \mathrm{C}$ for $2 \mathrm{~h}$ (the $1^{\text {st }}$ stage). Two groups (group A and B) of Co/N-MPCs were synthesized to investigate the influences of $\mathrm{CO}_{2}$ and carbonization temperature on the catalytic activity. Group A catalysts were prepared through template removal (via $\mathrm{HCl}$ etching) after the $2^{\text {nd }}$ stage heat treatment of the composite at $500-900{ }^{\circ} \mathrm{C}$ for
$3 \mathrm{~h}$. The obtained template-removed precursors were then carbonized at $900{ }^{\circ} \mathrm{C}$ for $2 \mathrm{~h}$ (the $3^{\text {rd }}$ stage), as shown in Fig. 1 . For convenience, this heat treatment temperature was named as template removal temperature (TRT), and the obtained catalyst was named as Co/N-MPC(TRT/900). Group B catalysts named as $\mathrm{Co} / \mathrm{N}-\mathrm{MPC}(650 / 700-900)$ were prepared via the carbonization of the template-removed precursor (TRT: $650{ }^{\circ} \mathrm{C}$ ) at $700-900{ }^{\circ} \mathrm{C}$ for $2 \mathrm{~h}$. For comparison, the N-containing MPC (N-MPC) or the cobalt-doped $\mathrm{N}$-containing carbon $(\mathrm{Co} / \mathrm{N}-\mathrm{C})$ were prepared without the addition of $\mathrm{Co}\left(\mathrm{NO}_{3}\right)_{2} \cdot 6 \mathrm{H}_{2} \mathrm{O}$ or the template. All heat treatments were conducted under $\mathrm{N}_{2}$ atmosphere.

\subsection{Physical characterization}

The structure and the morphology of the synthesized samples were characterized by X-ray diffraction (XRD) using a Rigaku-D/ MAX-2550PC diffractometer with $\mathrm{Cu}-\mathrm{K} \alpha$ radiation $(\lambda=1.5406$ $\AA ̊$ ), ULTRA55 scanning electron microscopy (SEM, Zeiss Corp.), and transmission electron microscopy (TEM, Hitachi H-9500) at $300 \mathrm{kV}$. Nitrogen content in the synthesized catalyst was determined using an oxygen/nitrogen/hydrogen elemental analyzer (LECO ONH836). The $\mathrm{N}$ species and their relative contents in the synthesized catalysts were determined via X-ray photoemission spectroscopy (XPS) using a PHI-5000C ESCA system (Perkin Elmer) with $\mathrm{Mg} \mathrm{K} \alpha$ radiation $(h \nu=1253.6 \mathrm{eV})$. All spectra were referenced to the $\mathrm{C}$ ls level at $284.6 \mathrm{eV}$ to correct the peak shift that occurred because of charge accumulation on the sample. Raw data were fitted and deconvoluted using the XPS Peak 4.1 software.

\subsection{Electrochemical measurements}

The catalytic activity of the synthesized catalysts was evaluated in a three-electrode system using the CHI 1140A electrochemical
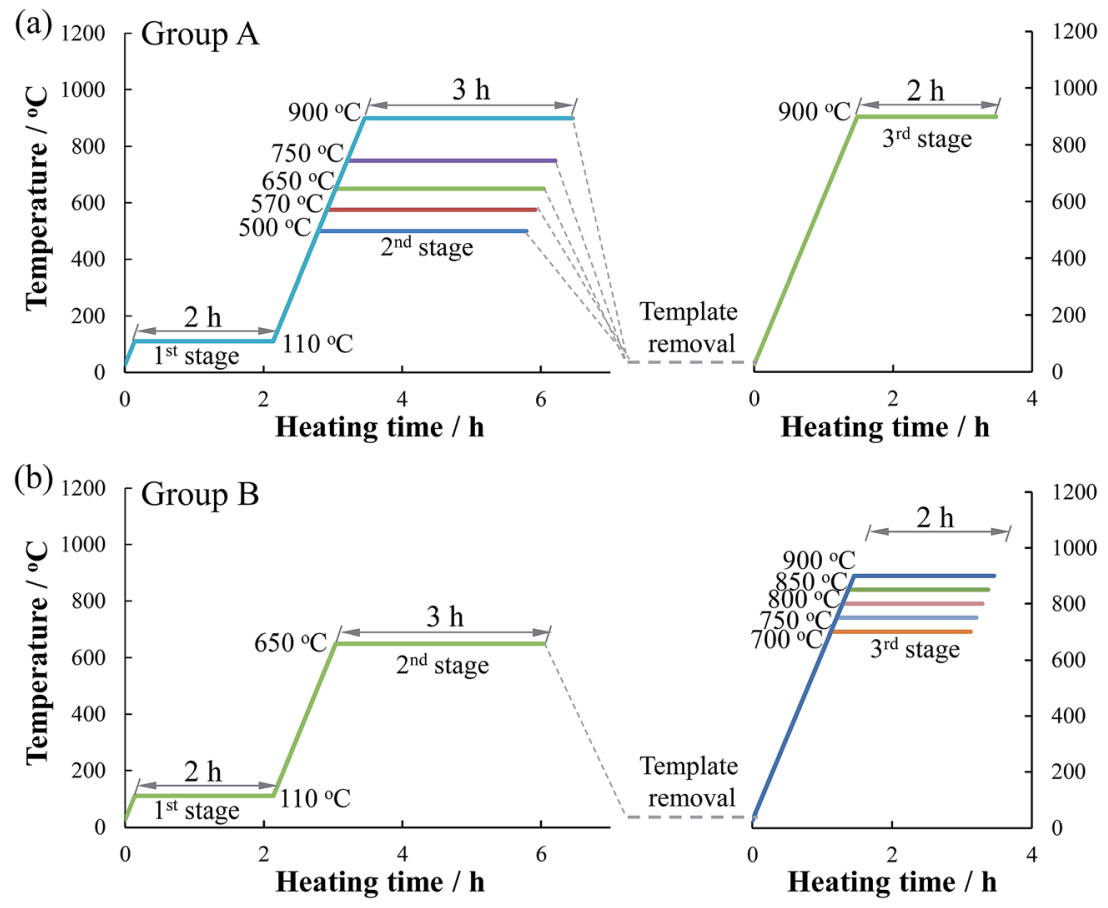

Fig. 1 Preparation procedures of Co/N-MPCs from the mixture of Co-coordinated glucose-urea resin with template; heating rate: $10^{\circ} \mathrm{C}$ min ${ }^{-1}$. 
workstation ( $\mathrm{CH}$ Instruments), with a disk electrode as the working electrode. Linear sweep voltammetry (LSV) analysis was conducted using a rotating disk electrode (RDE) (RDE-2, BASi Inc.) to evaluate the catalytic activity in both alkaline and acidic electrolytes. The electron transfer number of the ORR $(n)$ was estimated based on the Koutecky-Levich equation:

$$
I^{-1}=I_{\mathrm{k}}{ }^{-1}+\left\{0.62 n F A_{\mathrm{e}} C_{0} D_{0}{ }^{2 / 3} v^{-1 / 6} \omega^{1 / 2}\right\}^{-1}
$$

where $I$ is the disk current, $I_{\mathrm{k}}$ is the kinetic current, $\omega$ is the angular frequency of rotation, $F$ is the Faraday constant, and $A_{\mathrm{e}}$ is the electroactive area of the applied catalyst. The reported data for the $\mathrm{O}_{2}$ saturated concentrations $\left(C_{0}\right)$, diffusion coefficients $\left(D_{0}\right)$ of $\mathrm{O}_{2}$ in $0.1 \mathrm{M} \mathrm{KOH}$ and $0.5 \mathrm{M} \mathrm{H}_{2} \mathrm{SO}_{4}$ solutions, and kinematic viscosities $(\nu)$ of the $0.1 \mathrm{M} \mathrm{KOH}$ and $0.5 \mathrm{M} \mathrm{H}_{2} \mathrm{SO}_{4}$ solutions were used. ${ }^{\mathbf{4 0 , 4 1}}$ The potentials were converted into the values vs. reversible hydrogen electrode (RHE) according to the $\mathrm{pH}$ value of the applied electrolyte as follows: ${ }^{\mathbf{4 2}}$

$E(\mathrm{~V} v s . \mathrm{RHE})=E(\mathrm{~V} v s . \mathrm{SCE})+0.241+0.0591 \times \mathrm{pH}$, at $25^{\circ} \mathrm{C}$

The catalyst sample $(8.0 \mathrm{mg})$, ethanol $(3 \mathrm{~mL})$, and Nafion solution $(0.2 \mathrm{~mL}, 5 \mathrm{wt} \%)$ were ultrasonically mixed to form the homogenous catalyst ink. The catalyst slurry $(5 \mu \mathrm{L})$ was pipetted onto the polished glass carbon electrode ( $3 \mathrm{~mm}$ in diameter). A calomel electrode in saturated $\mathrm{KCl}$ solution (SCE) and Pt-wire electrode were used as the reference and counter electrodes, respectively. A salt bridge was used to connect the reference electrode to the cell. RDE LSVs were obtained using $0.1 \mathrm{M} \mathrm{KOH}$ and $0.5 \mathrm{M} \mathrm{H}_{2} \mathrm{SO}_{4}$ solutions saturated with $\mathrm{O}_{2}$ at $25{ }^{\circ} \mathrm{C}$.

A test cell with an active area of $6 \mathrm{~cm}^{2}$ was assembled to evaluate the performance of the synthesized catalyst in a direct borohydride fuel cell (DBFC). The cathode and anode catalyst inks were prepared by mixing the catalyst powder, Nafion solution (5 wt\%), deionized water, and ethanol in a mass ratio of $1: 7: 3: 3$, respectively. The cathode was prepared by coating $3.0 \mathrm{mg} \mathrm{cm}^{-2}$ of the synthesized catalyst on a piece of hydrophobic carbon cloth, and then heating at $130{ }^{\circ} \mathrm{C}$ for $2 \mathrm{~h}$. The anodes were prepared by coating the commercial $\mathrm{Pt} / \mathrm{XC}-72$ catalyst $(20 \mathrm{wt} \% \mathrm{Pt}$,
$3.0 \mathrm{mg} \mathrm{cm}{ }^{-2}$ ) on a piece of Ni foam. Nafion 112 membrane was sequentially boiled in $3 \mathrm{wt} \% \mathrm{H}_{2} \mathrm{O}_{2}$ solution, deionized water, $0.5 \mathrm{M} \mathrm{H}_{2} \mathrm{SO}_{4}$, and deionized water for $30 \mathrm{~min}$. An alkaline borohydride solution ( $5 \mathrm{wt} \% \mathrm{NaBH}_{4}$ in $10 \mathrm{wt} \% \mathrm{NaOH}$ ) was used as a fuel to run the cell. Cell performance was measured at a fuel flow rate of $15 \mathrm{~mL} \mathrm{~min}^{-1}$ and a dry $\mathrm{O}_{2}$ flow rate of $150 \mathrm{~mL} \mathrm{~min}^{-1}$ at $25{ }^{\circ} \mathrm{C}$. The cell figuration and performance evaluation system was described in a previous study. ${ }^{7}$

\section{Results and discussion}

\subsection{Effects of the template}

To verify the influence of $\mathrm{CaCO}_{3}$ decomposition during carbonization on the catalytic activity towards ORR, the RDE

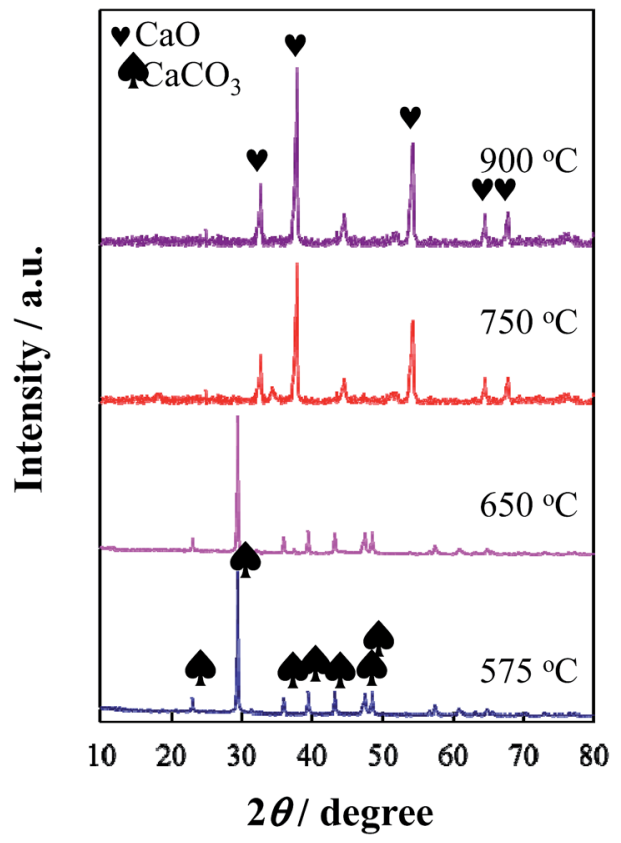

Fig. 3 XRD patterns of the composites consisting of Co-coordinated glucose-urea resin and $\mathrm{CaCO}_{3}$ after heat treatment at $575-900^{\circ} \mathrm{C}$ for $3 \mathrm{~h}$.
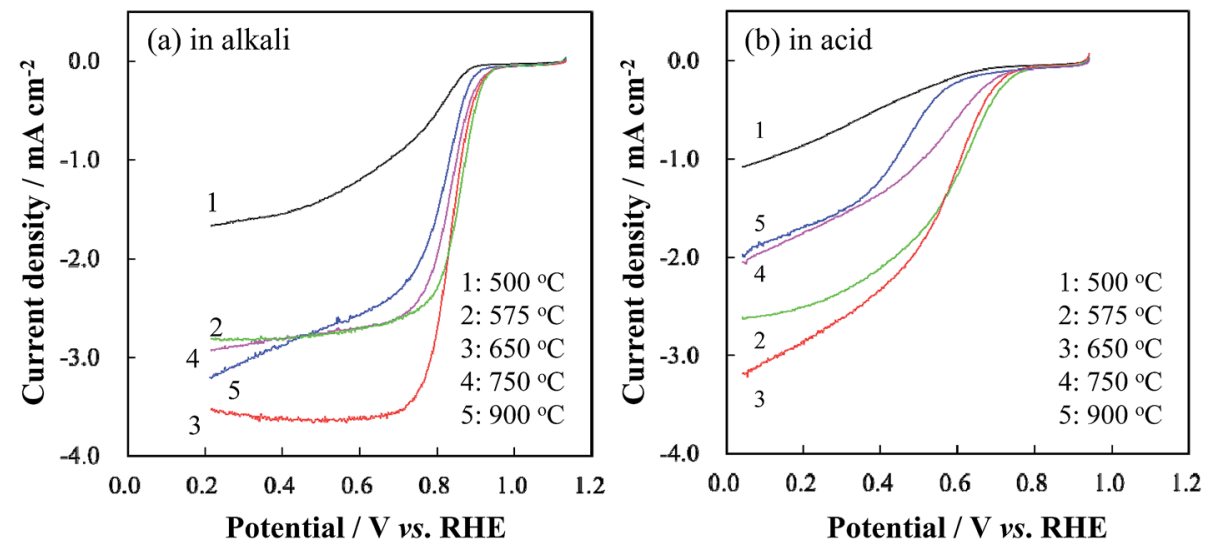

Fig. 2 RDE LSV curves of Co/N-MPCs in group A (TRT: $500-900^{\circ} \mathrm{C}$ ) in (a) $0.1 \mathrm{M} \mathrm{KOH}$ and (b) $0.5 \mathrm{M} \mathrm{H}_{2} \mathrm{SO}_{4}$ solutions at a scan rate of $5 \mathrm{mV} \mathrm{s}{ }^{-1}$ and a rotation rate of $900 \mathrm{rpm}$. 
LSVs of the group A catalysts were measured, as shown in Fig. 2. When TRT increased from 500 to $650{ }^{\circ} \mathrm{C}$, the ORR current and the on-set potential of the obtained catalyst increased. However, further increase of TRT led to a decrease in the ORR current and on-set potential.

XRD results showed that $\mathrm{CaCO}_{3}$ remained stable when the composite consisting of Co-coordinated glucose-urea resin and $\mathrm{CaCO}_{3}$ was heated at temperatures below $650{ }^{\circ} \mathrm{C}$, whereas decomposed into $\mathrm{CaO}$ and $\mathrm{CO}_{2}$ when heated over $750{ }^{\circ} \mathrm{C}$ (Fig. 3). Based on the $\mathrm{N}_{2}$ adsorption-desorption isotherm measurements (Fig. S1 $\dagger$ ), Co/N-MPC(650/900) presented a smaller specific surface area $\left(322.8 \mathrm{~m}^{2} \mathrm{~g}^{-1}\right)$ and total pore volume $(0.50$ $\left.\mathrm{cm}^{3} \mathrm{~g}^{-1}\right)$, whereas larger average pore diameter $(21.2 \mathrm{~nm})$ than Co/N-MPC(900/900) (561.3, $\mathrm{m}^{2} \mathrm{~g}^{-1}, 0.50 \mathrm{~cm}^{3} \mathrm{~g}^{-1}$, and $12.8 \mathrm{~nm}$, respectively) as presented in Table $\mathrm{S} 1 . \dagger$ These results imply that $\mathrm{CO}_{2}$ generated from $\mathrm{CaCO}_{3}$ decomposition reacted with carbon at higher pyrolysis temperatures, leading to the creation of more meso- and micro-pores (inset of Fig. $\mathrm{S} 1 \dagger$ ). ${ }^{43}$ As a result, the specific surface area of the Co/N-MPC(900/900) was larger than that of the $\mathrm{Co} / \mathrm{N}-\mathrm{MPC}(650 / 900)$.

The Co/N-MPC(900/900) had higher specific surface area, but contained much less nitrogen than the Co/N-MPC(650/900), as presented in Table 1. Based on the reported binding energies of Co- $\mathrm{N}_{x}$, pyridinic- $\mathrm{N}$, pyrrolic- $\mathrm{N}$, graphitic- $\mathrm{N}$, and pyridinic- $\mathrm{N}$ oxide

Table 1 Contents (at\%) of elements in Co/N-MPCs synthesized with different templates and template removal temperatures

\begin{tabular}{lllll}
\hline & $\mathrm{C}$ & $\mathrm{O}$ & $\mathrm{N}$ & $\mathrm{Co}$ \\
\hline $\mathrm{Co} / \mathrm{N}-\mathrm{MPC}(650 / 900)$ & 82.53 & 10.98 & 5.79 & 0.70 \\
$\mathrm{Co} / \mathrm{N}-\mathrm{MPC}(900 / 900)$ & 87.34 & 10.18 & 1.38 & 1.10 \\
$\mathrm{Co} / \mathrm{N}-\mathrm{MPC}\left(\mathrm{SiO}_{2}\right)$ & 81.64 & 11.85 & 5.95 & 0.55 \\
$\mathrm{Co} / \mathrm{N}-\mathrm{C}$ & 81.51 & 10.90 & 7.59 & 0.01
\end{tabular}

(398.0, 398.5, 400.0, 401.1, and 403.0 eV, respectively), ${ }^{\mathbf{2 6 4 4 - 4 7}}$ spectral deconvolution of $\mathrm{N}$ 1s core level spectrum was conducted, as shown in Fig. 4. Four peaks (assigned to $\mathrm{Co}-\mathrm{N}_{x}$, pyridinic-N, pyrrolic-N, and graphitic-N) appeared in the spectra of $\mathrm{Co} / \mathrm{N}$ MPC(650/900) and Co/N-MPC(900/900). One more peak appeared in the spectrum of $\mathrm{Co} / \mathrm{N}-\mathrm{MPC}(900 / 900)$, assigned to pyridinic- $\mathrm{N}$ oxide. Co- $\mathrm{N}_{x}$, pyridinic- $\mathrm{N}$, and graphitic- $\mathrm{N}$ were the active-sites for ORR. ${ }^{47-52}$ Compared with the Co/N-MPC(650/900), the lower catalytic activity of the Co/N-MPC(900/900) (in Fig. 2) was attributed to the lower contents of Co- $\mathrm{N}_{x}$, pyridinic- $\mathrm{N}$, and graphitic-N in the $\mathrm{Co} / \mathrm{N}-\mathrm{MPC}(900 / 900)$ (Table 2), which suggests that higher $\mathrm{CaCO}_{3}$ removal temperature led to a more severe destruction of the active $\mathrm{N}$ species. These results imply that $\mathrm{CO}_{2}$ from $\mathrm{CaCO}_{3}$ decomposition led to a decrease in the number of active sites.

It is indicated that the carbon-nitrogen bond in the active sites is strongly polarized towards nitrogen (the electronegativities of $\mathrm{C}$ and $\mathrm{N}$ are 2.55 and 3.04, respectively). Nucleophilic $\mathrm{CO}_{2}$ tends to attack the electropositive carbon atoms bonded to $\mathrm{N}$ prior to those bonded through a covalent bond of $\mathrm{C}-\mathrm{C}$, breaking the $\mathrm{C}-\mathrm{N}$ bond and forming $\mathrm{CO}$, thereby leading to the destruction of pyridinic- $\mathrm{N}$ and graphitic- $\mathrm{N}$ and the release of nitrogen. To verify the relation between the $\mathrm{CaCO}_{3}$ template and the $\mathrm{N}$ loss, the $\mathrm{Co} / \mathrm{N}-\mathrm{MPC}\left(\mathrm{SiO}_{2}\right)$ was synthesized by employing $\mathrm{SiO}_{2}$ template. $\mathrm{SiO}_{2}$ was removed by $\mathrm{HF}$ acid. The morphology of $\mathrm{Co} / \mathrm{N}-\mathrm{MPC}\left(\mathrm{SiO}_{2}\right)$ was similar to that of $\mathrm{Co} / \mathrm{N}-\mathrm{MPC}(900 / 900)$, as shown in Fig. 5, but exhibited higher $\mathrm{N}$ content (Table 1). Moreover, the $\mathrm{Co} / \mathrm{N}-\mathrm{C}$ prepared without template also showed much higher $\mathrm{N}$ content than the Co/N-MPC(900/900). These results indicate that the $\mathrm{Co} / \mathrm{N}-\mathrm{MPC}$ fabricated with a stable template yielded a high content of nitrogen, suggesting that $\mathrm{CO}_{2}$ resulted in the $\mathrm{N}$ loss.

The decisive evidence for carbon erosion and $\mathrm{N}$ loss was obtained through the pyrolysis of the Co/N-MPC(650/900) with
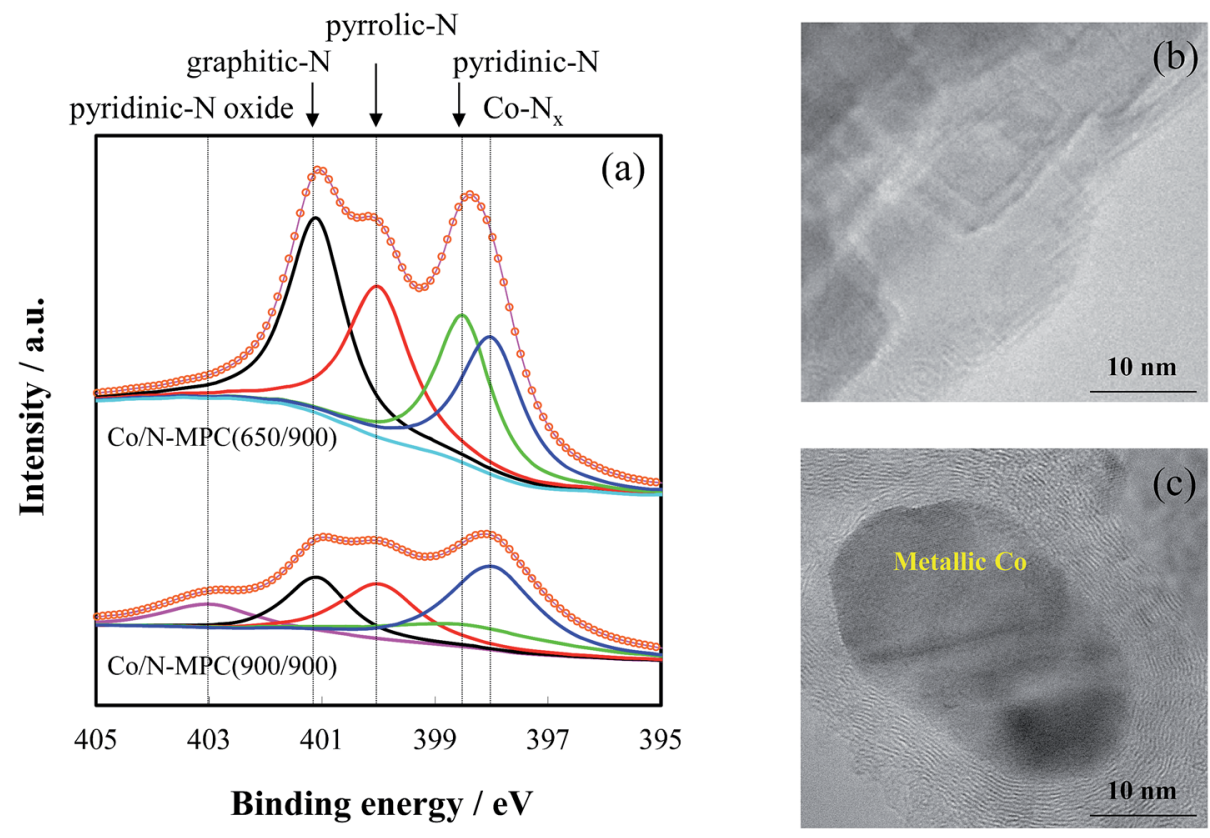

Fig. 4 Normalized N 1s spectra (a) and TEM images of Co/N-MPC(650/900) (b) and Co/N-MPC(900/900) (c). 
Table 2 Contents (at\%) of N-species in Co/N-MPC(650/900) and Co/N-MPC(900/900) ${ }^{a}$

\begin{tabular}{llllll}
\hline & $\begin{array}{l}\text { Co- } \mathrm{N}_{x} \\
398.0 \mathrm{eV}\end{array}$ & $\begin{array}{l}\text { Pyridinic-N } \\
398.5 \mathrm{eV}\end{array}$ & $\begin{array}{l}\text { Pyrrolic-N } \\
400.0 \mathrm{eV}\end{array}$ & $\begin{array}{l}\text { Graphitic-N } \\
401.1 \mathrm{eV}\end{array}$ & $\begin{array}{l}\text { Pyridinic-N oxide } \\
403.0 \mathrm{eV}\end{array}$ \\
\hline Co/N-MPC(900/900) & $0.47(33.90)$ & $0.26(18.87)$ & $0.28(20.30)$ & $0.22(16.20)$ & $0.15(10.73)$ \\
Co/N-MPC(650/900) & $1.33(22.99)$ & $1.27(21.86)$ & $1.48(25.50)$ & $1.72(29.65)$ & $0(0)$
\end{tabular}

${ }^{a}$ Data in brackets account for each N-species ratio in the total $\mathrm{N}$ content of Co/N-MPC.

$\mathrm{CaCO}_{3}$ (the mass ratios of $\mathrm{CaCO}_{3}$ to $\mathrm{Co} / \mathrm{N}-\mathrm{MPC}$ were $10: 3$ and $30: 3$, respectively) at $900{ }^{\circ} \mathrm{C}$. The nano- $\mathrm{CaCO}_{3}$ powders were placed at the bottom of a crucible, separated from the $\mathrm{Co} / \mathrm{N}$ MPC(650/900) lump with a piece of ceramic filter. After heating for $2 \mathrm{~h}$, the weight loss and the remaining contents of carbon, nitrogen, and hydrogen in the Co/N-MPC are tabulated in Table 3. The decrease in the sample weight and $\mathrm{N}$ content proved that the carbon erosion and the $\mathrm{N}$ loss were caused by $\mathrm{CO}_{2}$.

A more controllable experiment was conducted by loading $\mathrm{CaCO}_{3}$ to the $\mathrm{Co} / \mathrm{N}-\mathrm{MPC}(650 / 900) . \mathrm{Na}_{2} \mathrm{CO}_{3}$ solutions (with $0.021,0.085$, and $0.17 \mathrm{~g}$ of $\mathrm{Na}_{2} \mathrm{CO}_{3}$ in $10 \mathrm{~mL}$ of water) were dropwise added to $100 \mathrm{~mL}$ of a suspension containing $\mathrm{Co} / \mathrm{N}$ $\operatorname{MPC}(650 / 900)(1 \mathrm{~g})$ and $\mathrm{CaCl}_{2}(0.022,0.089$, and $0.178 \mathrm{~g}$, respectively) under stirring for $4 \mathrm{~h}$. The $\mathrm{CaCO}_{3}$-loaded $\mathrm{Co} / \mathrm{N}$ MPCs were then pyrolyzed at $900{ }^{\circ} \mathrm{C}$ for $2 \mathrm{~h}$. The $\mathrm{CO}_{2}$-treated $\mathrm{Co} / \mathrm{N}-\mathrm{MPC}$ was then obtained after $\mathrm{CaO}$ removal through $\mathrm{HCl}$
Table 3 Weight loss and contents (wt\%) of carbon, nitrogen, and hydrogen remaining in Co/N-MPC after heating Co/N-MPC(650/900) with $\mathrm{CaCO}_{3}$ at $900{ }^{\circ} \mathrm{C}$ for $2 \mathrm{~h}$

\begin{tabular}{|c|c|c|c|c|}
\hline $\begin{array}{l}\text { Mass ratio of } \\
\mathrm{CaCO}_{3} \text { to } \mathrm{Co} / \mathrm{N}-\mathrm{MPC}\end{array}$ & Weight/g & $\mathrm{C} / \mathrm{wt} \%$ & N/wt $\%$ & $\mathrm{H} / \mathrm{wt} \%$ \\
\hline Co/N-MPC(650/900) & 0.30 & 80.91 & 5.01 & 1.78 \\
\hline $0: 3$ & 0.29 & 80.24 & 4.73 & 1.47 \\
\hline $10: 3$ & 0.15 & 72.77 & 2.85 & 1.00 \\
\hline $30: 3$ & 0.08 & 62.08 & 2.10 & 0.77 \\
\hline
\end{tabular}

etching. The influence of the loaded $\mathrm{CaCO}_{3}$ amount on the catalytic activity was evaluated in $0.5 \mathrm{M} \mathrm{H}_{2} \mathrm{SO}_{4}$, as shown in Fig. 6. It was found that both the ORR current and its potential significantly decreased when the loaded $\mathrm{CaCO}_{3}$ amount in the $\mathrm{Co} / \mathrm{N}-\mathrm{MPC}(650 / 900)$ was increased (mass ratio of $\mathrm{CaCO}_{3}$ to the
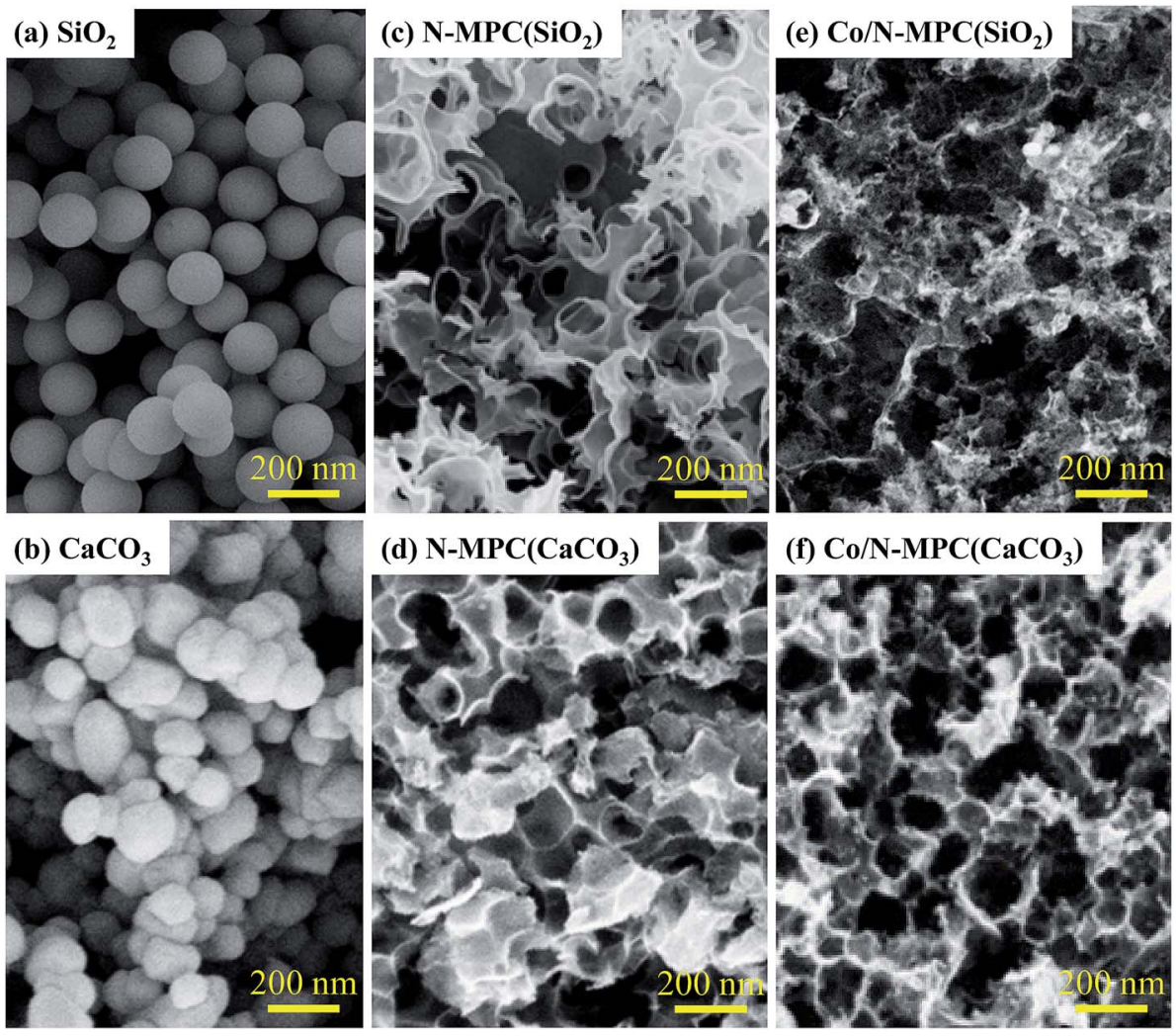

Fig. 5 SEM images of (a) $\mathrm{SiO}_{2}$ and (b) $\mathrm{CaCO}_{3}$ templates, (c, d) N-MPCs, and (e, f) Co/N-MPCs prepared with $\mathrm{SiO}_{2}$ (c, e) and CaCO (d, f) templates. Mass ratio of glucose (in glucose-resin) to template $=1: 2$ 


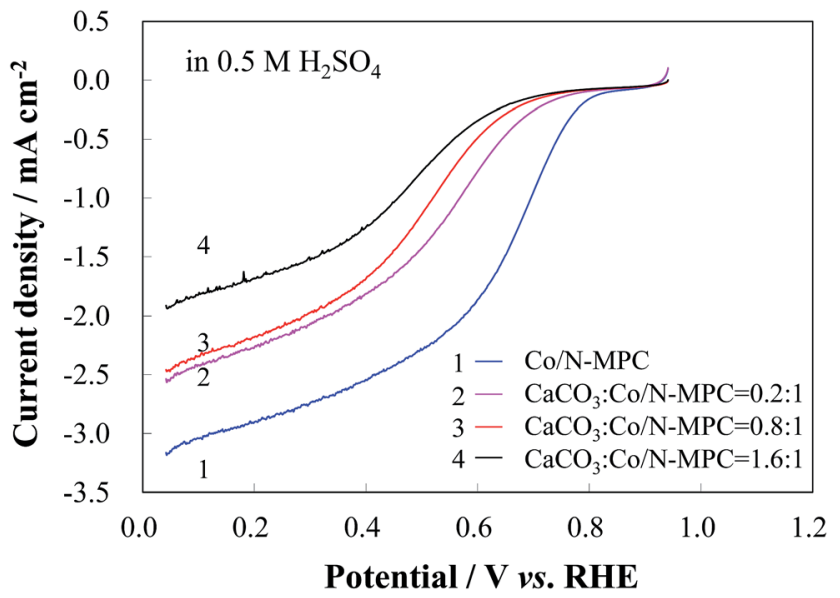

Fig. 6 RDE LSV curves of $\mathrm{CO}_{2}$-treated $\mathrm{Co} / \mathrm{N}-\mathrm{MPC}(650 / 900)$ with various loading amounts of $\mathrm{CaCO}_{3}$, in $0.5 \mathrm{M} \mathrm{H}_{2} \mathrm{SO}_{4}$ solution at a scan rate of $5 \mathrm{mV} \mathrm{s}^{-1}$ and a rotation rate of $900 \mathrm{rpm}$.

$\mathrm{Co} / \mathrm{N}-\mathrm{MPC}=0: 1,0.2: 1,0.8: 1$, and $1.6: 1)$. This result confirmed that the catalyst deterioration was caused by $\mathrm{CO}_{2}$ generated from the $\mathrm{CaCO}_{3}$ decomposition.

\subsection{Effects of carbonization temperature}

The formation of metallic Co in Co/N-MPC(900/900) (Fig. 4(c)) not only showed evidence of Co- $\mathrm{N}_{x}$ site destruction, but also suggested that $\mathrm{Co}-\mathrm{N}_{x}$ was unstable at $900{ }^{\circ} \mathrm{C}$. To understand the effect of carbonization temperature on the active-site destruction, the content of $\mathrm{N}$-species in $\mathrm{Co} / \mathrm{N}-\mathrm{MPC}(650 / 800)$ and $\mathrm{Co} / \mathrm{N}-$
MPC(650/900) were measured by XPS. The quantitative analysis results revealed that the $\mathrm{Co} / \mathrm{N}-\mathrm{MPC}(650 / 900)$ contained less nitrogen than $\mathrm{Co} / \mathrm{N}-\mathrm{MPC}(650 / 800)$, as tabulated in Table 4 . All $\mathrm{N}$ species contents were decreased, and Co- $\mathrm{N}_{x}$ species showed a larger loss than other species, indicating that destruction of these active sites occurred at $900{ }^{\circ} \mathrm{C}$.

The RDE LSV curves of Co/N-MPCs, obtained after the carbonization of the template-removed precursor (TRT: $650{ }^{\circ} \mathrm{C}$ ) at $700-900{ }^{\circ} \mathrm{C}$, were obtained in alkaline and acidic electrolytes, as shown in Fig. 7. The ORR current and onset potential increased when the carbonization temperature was increased from 700 to $800{ }^{\circ} \mathrm{C}$, which is ascribed to the increase in the electrical conductivity of the MPC because of its graphitization degree improvement. ${ }^{53}$ However, further increase in the carbonization temperature over $800{ }^{\circ} \mathrm{C}$ showed a negative effect on the ORR kinetics, indicating that the active site destruction occurred at temperatures over $800{ }^{\circ} \mathrm{C}$.

Like other nitrogen-doped carbon catalysts, ${ }^{54}$ the $\mathrm{Co} / \mathrm{N}$ MPC(650/800) showed higher ORR current and on-set potential in alkali than those in acid, as shown in Fig. 8. Regarding the polarity of the $\mathrm{N}$ species, $\mathrm{N}$ acts as a nucleophilic center because of its lone pair of electrons, whereas the connected $\mathrm{C}$ or Co becomes an electrophilic center. Both nucleophiles, such as dioxygen and water (ORR reactants in alkali), can absorb at the same electrophilic center such as the Co position prior to the $\mathrm{N}$ position in the case of a Co- $\mathrm{N}_{x}$ site. ${ }^{55}$ However, as ORR reactants in acid, dioxygen (nucleophile), and proton (electrophile) have to be separately absorbed at the Co and $\mathrm{N}$ positions. The larger ORR polarization of the Co/N-MPC(650/800) in acid than that in alkali can be attributed to the space steric effect of the Co-N

Table 4 Contents (at\%) of N-species in Co/N-MPC(650/800) and Co/N-MPC(650/900) ${ }^{a}$

\begin{tabular}{|c|c|c|c|c|c|}
\hline Co/N-MPC(650/800) & $1.90(29.15)$ & $1.36(20.78)$ & $1.51(23.06)$ & $1.76(27.01)$ & 6.53 \\
\hline
\end{tabular}

${ }^{a}$ Data in brackets account for each $\mathrm{N}$-species ratio in the total $\mathrm{N}$ content of $\mathrm{Co} / \mathrm{N}-\mathrm{MPC}$.
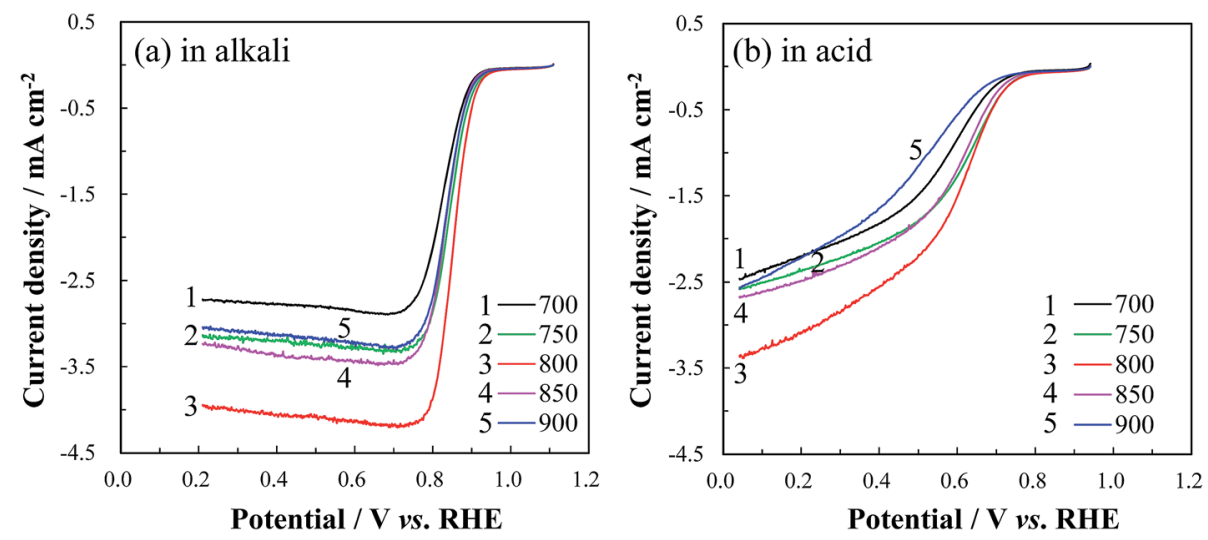

Fig. 7 RDE LSV curves of Co/N-MPCs (group B) obtained after the carbonization of the template-removed precursor (TRT: $650{ }^{\circ} \mathrm{C}$ ) at $700-$ $900{ }^{\circ} \mathrm{C}$, in (a) $0.1 \mathrm{M} \mathrm{KOH}$ and (b) $0.5 \mathrm{M} \mathrm{H}_{2} \mathrm{SO}_{4}$ solutions at a scan rate of $5 \mathrm{mV} \mathrm{s}^{-1}$ and a rotation rate of $900 \mathrm{rpm}$. 

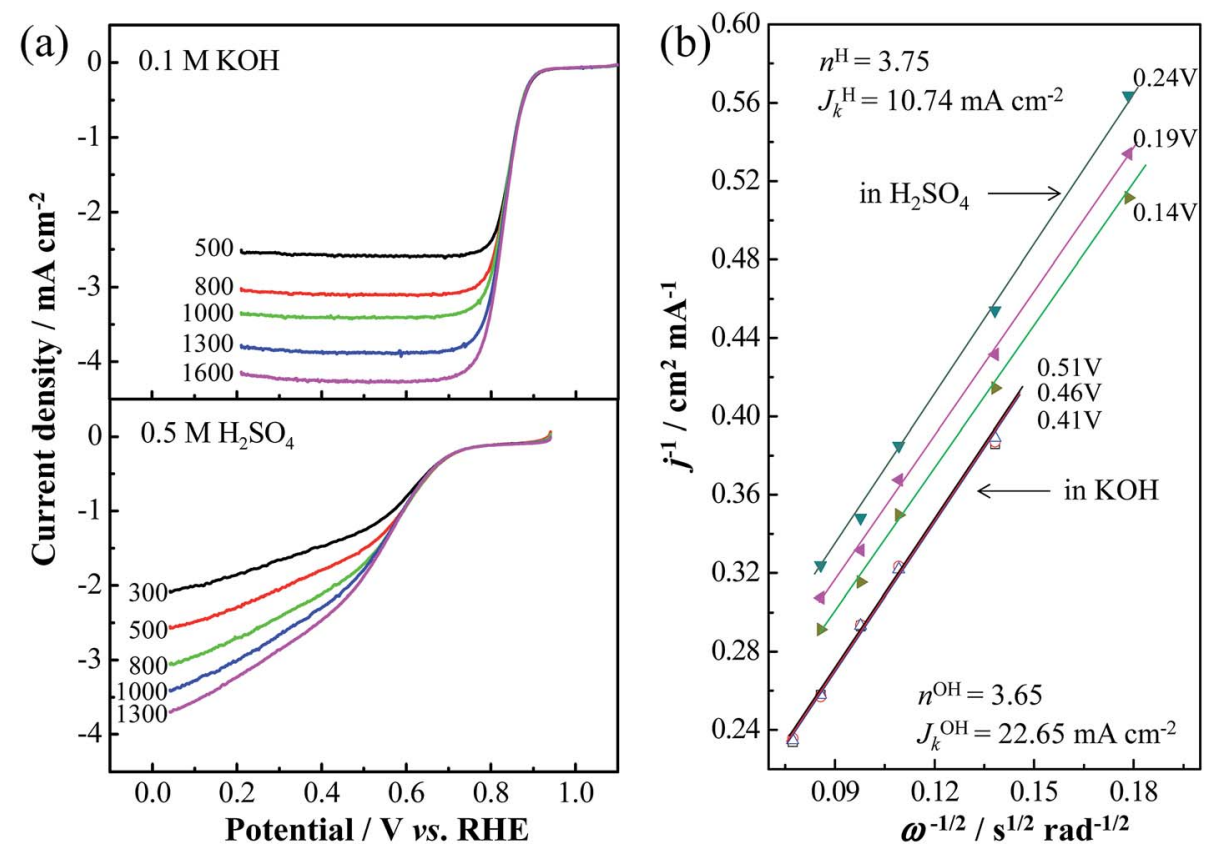

Fig. 8 (a) RDE LSVs of $\mathrm{Co} / \mathrm{N}-\mathrm{MPC}(650 / 800)$ in $\mathrm{O}_{2}$ saturated $0.1 \mathrm{M} \mathrm{KOH}$ and $0.5 \mathrm{M} \mathrm{H}_{2} \mathrm{SO}_{4}$ solutions at various rotation rates. Scan rate: $10 \mathrm{mV} \mathrm{s}$. (b) The $\mathrm{K}-\mathrm{L}$ plots at $0.14,0.19$, and $0.24 \mathrm{~V}$ vs. RHE in $0.5 \mathrm{M} \mathrm{H}_{2} \mathrm{SO}_{4}$, and $0.41,0.46$, and $0.51 \mathrm{~V}$ vs. RHE in a $0.1 \mathrm{M} \mathrm{KOH}$.
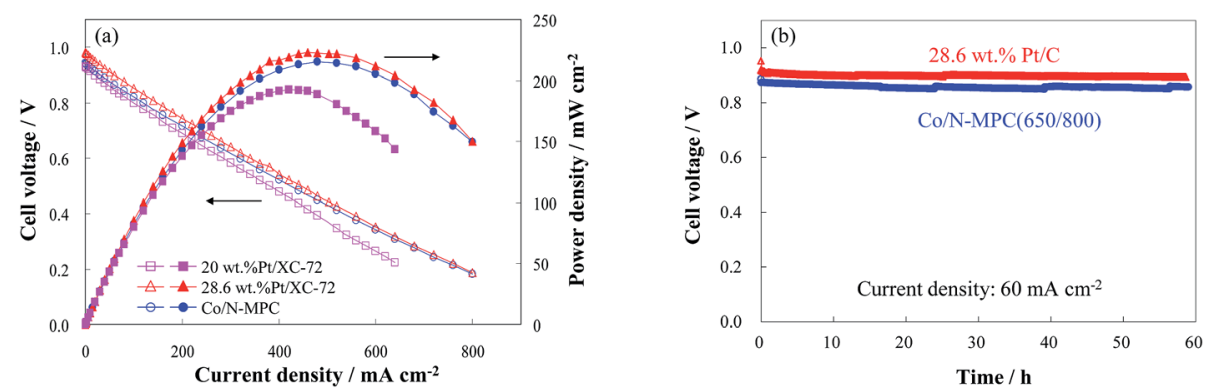

Fig. 9 Performance (a) and performance stabilities (b) of the DBFCs using the Co/N-MPC(650/800) and commercial Pt/XC-72 as the cathode catalyst under ambient conditions. Catalyst loading in cathode and anode: $3 \mathrm{mg} \mathrm{cm}^{-2}$, anode catalyst: $20 \mathrm{wt} \% \mathrm{Pt} / \mathrm{C}$, electrolyte: Nafion 112 . Fuel: $5 \mathrm{wt} \% \mathrm{NaBH}_{4}$ and $10 \mathrm{wt} \% \mathrm{NaOH}$ solution at a flow rate of $15 \mathrm{~mL} \mathrm{~min}^{-1}$. Dry $\mathrm{O}_{2}$ at $150 \mathrm{~mL} \mathrm{~min}{ }^{-1}$.

bond. Regarding the K-L equation (eqn (1)) and RDE LSV results at various rotation rates, the calculated $n$ values obtained from the $\mathrm{Co} / \mathrm{N}-\mathrm{MPC}(650 / 800)$ are 3.65 in $0.1 \mathrm{M} \mathrm{KOH}$ and 3.75 in $0.5 \mathrm{M}$ $\mathrm{H}_{2} \mathrm{SO}_{4}$ electrolytes. The kinetic current densities of the $\mathrm{Co} / \mathrm{N}$ MPC(650/800) reach 22.65 and $10.74 \mathrm{~mA} \mathrm{~cm}^{-2}$, respectively, revealing that the $\mathrm{Co} / \mathrm{N}-\mathrm{MPC}(650 / 800)$ is a remarkable non-Pt catalyst for fuel cells.

The performance of the Co/N-MPC(650/800) is verified in a DBFC, as shown in Fig. 9(a). A peak power density of $215 \mathrm{~mW}$ $\mathrm{cm}^{-2}$ has been achieved under ambient conditions, which is higher than the performance of the cells using commercial 20 wt $\% \mathrm{Pt} / \mathrm{C}$ catalyst $\left(190 \mathrm{~mW} \mathrm{~cm}^{-2}\right)$ and previously reported onestep prepared Co/N-MPC $\left(170 \mathrm{~mW} \mathrm{~cm}^{-2}\right)^{26}$ and carbonsupported $\mathrm{Co}_{3} \mathrm{O}_{4}\left(186 \mathrm{~mW} \mathrm{~cm}{ }^{-2}\right) .{ }^{55}$ The developed DBFC is comparable to the cell with $28.6 \mathrm{wt} \% \mathrm{Pt} / \mathrm{C}$ catalyst $(220 \mathrm{~mW}$ $\mathrm{cm}^{-2}$ ), showing good short-term performance stability comparable to that of the cell with $28.6 \mathrm{wt} \% \mathrm{Pt} / \mathrm{C}$ catalyst (Fig. 9(b)).

\section{Conclusions}

The N-containing MPC-supported cobalt (Co/N-MPC) catalyst with high performance was synthesized via multistep pyrolysis of composite containing Co-coordinated glucose-urea resin and nano- $\mathrm{CaCO}_{3}$ template. $\mathrm{CO}_{2}$ from $\mathrm{CaCO}_{3}$ decomposition attacked the carbon atoms bonded to $\mathrm{N}$, leading to catalyst deterioration caused by the active site destruction. Removal of $\mathrm{CaCO}_{3}$ template before its decomposition effectively suppressed the active site destruction. Nitrogen containing active sites were unstable at temperatures over $800{ }^{\circ} \mathrm{C}$.

Through the preparation of the template-removed precursor via $\mathrm{CaCO}_{3}$ removal at $650{ }^{\circ} \mathrm{C}$, the $\mathrm{Co} / \mathrm{N}$-MPC synthesized via the carbonization of the precursor at $800{ }^{\circ} \mathrm{C}(\mathrm{Co} / \mathrm{N}-\mathrm{MPC}(650 / 800))$ demonstrated high catalytic activity towards ORR in both alkaline and acidic electrolytes. The Co/N-MPC(650/800) reached electron transfer numbers of 3.65 and 3.75 , kinetic current 
densities of 22.65 and $10.74 \mathrm{~mA} \mathrm{~cm}^{-2}$ in $0.1 \mathrm{M} \mathrm{KOH}$ and $0.5 \mathrm{M}$ $\mathrm{H}_{2} \mathrm{SO}_{4}$ solutions, respectively. The direct borohydride fuel cell with $\mathrm{Co} / \mathrm{N}-\mathrm{MPC}(650 / 800)$ showed a power density as high as 215 $\mathrm{mW} \mathrm{cm}^{-2}$, which was higher than the value obtained from the

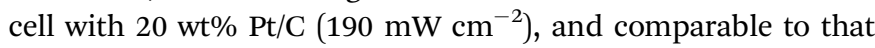
from the cell using $28.6 \mathrm{wt} \% \mathrm{Pt} / \mathrm{C}\left(220 \mathrm{~mW} \mathrm{~cm}^{-2}\right)$ as the cathode catalyst under ambient conditions.

The findings of this study bring a new insight to prevent the active site destruction. In fact, any oxidants generated from carbon sources and transition metal sources during catalyst synthesis may destroy active sites. Avoiding oxidant generation during catalyst synthesis is one of the most important steps in preparing high performance non-Pt catalysts for ORR.

\section{Acknowledgements}

This work is financially supported by the National Natural Science Foundation of China, Grant No. 21476200, 21276229 and 51271164; the Zhejiang Provincial Natural Science Foundation of China, Grant No. Z4110126.

\section{References}

1 Y. Nie, L. Li and Z. D. Wei, Chem. Soc. Rev., 2015, 44, 21682201.

2 Z. P. Li and B. H. Liu, J. Appl. Electrochem., 2010, 40, 475-483. 3 J. Y. Cheon, T. Kim, Y. M. Choi, H. Y. Jeong, M. G. Kim, Y. J. Sa, J. Kim, Z. Lee, T. H. Yang, K. Kwon, O. Terasaki, G. G. Park, R. R. Adzic and S. H. Joo, Sci. Rep., 2013, 3, 2715. 4 X. Zhang, D. Yu, Y. Zhang, W. Guo, X. Ma and X. He, RSC Adv., 2016, 6, 104183-104192.

5 G. Lalande, R. Cote, G. Ramizhmani, D. Guay, J. Dodelet, L. Dignard-Bailey, L. Weng and P. Bertrand, Electrochim. Acta, 1995, 40, 2635-2646.

6 M. Y. Ghotbi, B. Feli, M. Azadfalah and M. Javaheri, RSC Adv., 2015, 5, 92577-92584.

7 H. Y. Qin, Z. X. Liu, L. Q. Ye, J. K. Zhu and Z. P. Li, J. Power Sources, 2009, 192, 385-390.

8 R. Cote, G. Lalande, G. Faubert, D. Guay, J. P. Dodelet and G. Denes, J. Electrochem. Soc., 1998, 145, 2411-2418.

9 H. Wang, R. Cote, G. Faubert, D. Guay and J. P. Dodelet, J. Phys. Chem. B, 1999, 103, 2042-2049.

10 Z. Xu, H. Li, B. Yin, Y. Shu, X. Zhao, D. Zhang, L. Zhang, K. Li, X. Hou and J. Lu, RSC Adv., 2013, 3, 9344-9351.

11 H. Y Qin, Z. X Liu, S. J. Lao, J. K. Zhu and Z. P. Li, J. Power Sources, 2010, 195, 3124-3129.

12 C. Zhao, W. Wang, Z. Yu, H. Zhang, A. Wang and Y. Yang, J. Mater. Chem., 2010, 20, 976-980.

13 G. Xu, Y. Xu, J. Fang, X. Peng, F. Fu, L. Huang, J. Li and S. Sun, ACS Appl. Mater. Interfaces, 2013, 5, 10782-10793.

14 G. R. Li, Q. Q. Wang, B. H. Liu and Z. P. Li, Fuel Cells, 2015, 15, 270-277.

15 E. S. Toberer, T. D. Schladt and R. Seshadri, J. Am. Chem. Soc., 2006, 128, 1462-1463.

16 W. R. Li, D. H. Chen, Z. Li, Y. F. Shi, Y. Wan, J. J. Huang, J. J. Yang, D. Y. Zhao and Z. Y. Jiang, Electrochem. Commun., 2007, 9, 569-573.
17 P. Dibandjo, F. Chassagneux, L. Bois, C. Sigala and P. Miele, J. Mater. Chem., 2005, 15, 1917-1923.

18 B. Liu, H. Shioyama, T. Akita and Q. Xu, J. Am. Chem. Soc., 2008, 130, 5390-9391.

19 Z. L. Zhu, A. Li, L. Yan, F. Q. Liu and Q. X. Zhang, J. Colloid Interface Sci., 2007, 316, 628-634.

20 A. Vinu, K. Z. Hossian, P. Srinivasu, M. Miyahara, S. Anandan, N. Gokulakrishnan, T. Mori, K. Ariga and V. V. Balasubramanian, J. Mater. Chem., 2007, 17, 1819-1825.

21 S. Tanaka, Y. Katayama, M. P. Tate, H. W. Hillhouse and Y. Miyake, J. Mater. Chem., 2007, 17, 3639-3645.

22 Y. Liu, L. Zhan, R. Zhang, W. M. Qiao, X. Y. Liang and L. C. Ling, New Res. Carbon Mater., 2007, 22, 259-263.

23 K. P. Gierszal, M. Jaroniec, C. D. Liang and S. Dai, Carbon, 2007, 45, 2171-2177.

24 A. H. Janssen, I. Schmidt, C. J. H. Jacobsen, A. J. Koster and K. P. Jong, Microporous Mesoporous Mater., 2003, 65, 59-76.

25 C. Zhao, W. Wang, Z. Yu, H. Zhang, A. Wang and Y. Yang, J. Mater. Chem., 2010, 20, 976-980.

26 F. He, J. Yang, R. Li, B. H. Liu and Z. P. Li, J. Power Sources, 2015, 274, 48-55.

27 W. L. Cai, G. R. Li, F. He, L. M. Jin, B. H. Liu and Z. P. Li, J. Power Sources, 2015, 283, 524-529.

28 A. H. Lu, J. H. Smatt, M. Linden and F. Schuth, New Res. Carbon Mater., 2003, 18, 265-269.

29 J. Park, Y. Nabae, T. Hayakawa and M. Kakimoto, ACS Catal., 2014, 4, 3749-3754.

30 A. Vinu, K. Ariga, T. Mori, T. Nakanishi, S. Hishita, D. Golberg and Y. Bando, Adv. Mater., 2005, 17, 1648-1652.

31 S. S. Park, S. Chu, C. Xue, D. Zhao and C. Ha, J. Mater. Chem., 2011, 21, 10801-10807.

32 P. F. Fulvio, M. Jaroniec, C. Liang and S. Dai, J. Phys. Chem. C, 2008, 112, 13126-13133.

33 T. Fellinger, F. Hasche, P. Strasser and M. Antonietti, J. Am. Chem. Soc., 2012, 134, 4072-4075.

34 A. P. Wang, F. Y. Kang, Z. H. Huang, Z. C. Guo and X. Y. Chuan, Microporous Mesoporous Mater., 2008, 108, 318-324.

35 Y. Nabae, M. Malon, S. M. Lyth, S. Moriya, K. Matsubayashi, N. Islam, S. Kuroki, M. Kakimoto, J. Ozaki and S. Miyata, ECS Trans., 2009, 25, 463-467.

36 Y. Nabae, M. Sonada, C. Yamauchi, Y. Hosaka, A. Isoda and T. Aoki, Catal. Sci. Technol., 2014, 4, 1400-1406.

37 Z. P. Li, B. H. Liu, K. Arai and S. Suda, J. Alloys Compd., 2005, 404-406, 648-652.

38 P. Olu, N. Job and M. Chatenet, J. Power Sources, 2016, 327, 235-257.

39 Z. P. Li, B. H. Liu, K. Arai and S. Suda, J. Electrochem. Soc., 2003, 150, A868-A872.

40 D. Zhang, D. Chi, T. Okajima and T. Ohsaka, Electrochim. Acta, 2007, 52, 5400-5406.

41 M. H. Robson, A. Serov, K. Artyushkova and P. Atanassov, Electrochim. Acta, 2013, 90, 656-665.

42 K. Xu, S. J. Lao, H. Y. Qin, B. H. Liu and Z. P. Li, J. Power Sources, 2010, 195, 5606-5609.

43 G. Rasines, C. Macías, M. Haro, J. Jagiello and C. O. Ania, Microporous Mesoporous Mater., 2015, 209, 18-22. 
44 G. Liu, X. Li, P. Ganesan and B. Popov, Appl. Catal., B, 2009, 93, 156-165.

45 K. Lee, L. Zhang, H. Lui, R. Huim, Z. Shi and J. Zhang, Electrochim. Acta, 2009, 54, 4704-4711.

46 H. Wang, T. Maiyalagan and X. Wang, ACS Catal., 2012, 2, 781-794.

47 Z. X. Liu, B. H. Liu and Z. P. Li, Int. J. Hydrogen Energy, 2014, 39, 5689-5695.

48 C. W. B. Bezerra, L. Zhang, K. Lee, H. Liu, A. L. B. Marques, E. P. Marques, H. Wang and J. Zhang, Electrochim. Acta, 2008, 53, 4937-4951.

49 Z. P. Li, Z. X. Liu, K. N. Zhu, Z. Li and B. H. Liu, J. Power Sources, 2012, 219, 163-171.
50 M. Yuasa, A. Yamaguchi, H. Itsuki, K. Tanaka, M. Yamamoto and K. Oyaizu, Chem. Mater., 2005, 17, 4278-4281.

51 V. Nallathambi, J. W. Lee, S. P. Kumaraguru, G. Wu and B. N. Popov, J. Power Sources, 2008, 183, 34-42.

52 H. Y. Qin, K. N. Zhu, L. Q. Ye and Z. P. Li, J. Power Sources, 2012, 208, 203-209.

53 G. Xu, Y. Xu, J. Fang, X. Peng, F. Fu, L. Huang, J. Li and S. Sun, ACS Appl. Mater. Interfaces, 2013, 5, 10782-10793.

54 J. Yin, Y. Qiu, J. Yu, X. Zhou and W. Wu, RSC Adv., 2013, 3, 15655-15663.

55 B. H. Liu, L. T. Dou, F. He, J. Yang and Z. P. Li, RSC Adv., 2016, 6, 19025-19033. 